\title{
Clenbuterol Residue in Beef Meat Collected from Several Cities in Java Island, Indonesia
}

\author{
Widiastuti R, Anastasia Y \\ Indonesian Research Center for Veterinary Sciences \\ E-mail: widiastuti.raphaella@gmail.com \\ (received 02-02-2018; revised 07-05-2018; accepted 23-05-2018)
}

\begin{abstract}
ABSTRAK
Widiastuti R, Anastasia Y. 2018. Residu clenbuterol pada daging sapi yang dikoleksi dari beberapa kota di Pulau Jawa, Indonesia. JITV 23(2): 89-94. DOI: http://dx.doi.org/10.14334/jitv.v23i2.1621

Clenbuterol (CLB) merupakan obat hewan ilegal golongan $\beta$-agonis yang digunakan sebagai pemacu pertumbuhan pada berbagai hewan ternak. Keberadaan residu CLB pada produk ternak dapat menimbulkan keracunan pada manusia seperti tremor, takikardia, mual dan pusing. Tujuan dari penelitian ini adalah memvalidasi metode deteksi residu CLB pada daging sapi secara kromatografi cair kinerja tinggi (KCKT) serta mengetahui keberadaan residu CLB pada 74 sampel daging beku dan segar dari beberapa kota di pulau Jawa. Sampel diekstraksi dengan asetonitril dan isopropanol, kemudian dianalisis secara KCKT menggunakan kolom RP ODS $\mathrm{C}_{18}$ dan fasa gerak campuran $50 \mathrm{mM} \mathrm{NaH} \mathrm{PO}_{4}$ dan asetonitril (80:20, v/v) serta dideteksi menggunakan detektor photodiode array pada panjang gelombang $210 \mathrm{~nm}$. Hasil validasi metoda untuk parameter uji perolehan kembali pada penambahan CLB adalah 103,45; 89,27 dan 89,53\% untuk masing-masing penambahan konsentrasi sebesar 2, 5 dan $10 \mathrm{ng} / \mathrm{g}$ CLB. Nilai limit deteksi dan limit kuantitasi $0,10 \mathrm{ng} / \mathrm{g}$ dan $0,31 \mathrm{ng} / \mathrm{g}$. Hasil analisis terhadap 74 sampel, menunjukkan bahwa residu CLB terdeteksi pada 8 sampel dengan kisaran konsentrasi 2,40 hingga 15,06 ng/g dan telah melebihi batas maksimum residu CLB sebesar 0,2 ng/g. Untuk menghindari bahaya dari keberadaan residu CLB, diperlukan adanya monitoring terhadap bahan pangan asal ternak untuk menjamin keamanan pangan bagi konsumen.
\end{abstract}

Kata Kunci: Clenbuterol, Residu, Daging Sapi, KCKT

\begin{abstract}
Widiastuti R, Anastasia Y. 2018. Clenbuterol residue in beef meat collected from several cities In Java Island, Indonesia. JITV 23(2): 89-94. DOI: http://dx.doi.org/10.14334/jitv.v23i2.1621

Clenbuterol (CLB) is an illegally animal drug of the $\beta$-agonist group that used as a promoter of growth in various farm animals. The presence of CLB residues in livestock products can cause poisoning in humans, such as tremor, tachycardia, nausea and dizziness. The purpose of this research is to validate CLB residue detection method on beef meat detected using a high performance liquid chromatography (HPLC) and to determine the presence of CLB residue on 74 samples of frozen and fresh beef meat from several cities in Java. Samples were extracted with acetonitrile and isopropanol, then analyzed chromatographically using RP ODS $\mathrm{C}_{18}$ column and mixed mobile phases of $50 \mathrm{mM} \mathrm{NaH} \mathrm{PO}_{4}$ and acetonitrile $(80: 20$, v/v) and detected by photodiode array detector at a wavelength of $210 \mathrm{~nm}$. The recoveries were $103.45,89.27$ and $89.53 \%$ for each additional spiked at concentrations of 2, 5 and $10 \mathrm{ng} / \mathrm{g}$ of CLB. The detection limit and the quantitation limit were $0.10 \mathrm{ng} / \mathrm{g}$ and $0.31 \mathrm{ng} / \mathrm{g}$, respectively. Analysis of 74 samples showed that CLB residue was detected in 8 samples in a concentration range of 2.40 to $15.06 \mathrm{ng} / \mathrm{g}$ and had exceeded the CLB residue maximum limit of $0.2 \mathrm{ng} / \mathrm{g}$. To avoid the risk of the presence of CLB residues, it is necessary to regularly monitor the presence of residue of animal products to ensu re of food safety for consumers.
\end{abstract}

Key Words : Clenbuterol, Residue, Beef Meat, HPLC

\section{INTRODUCTION}

Clenbuterol (CLB) is one of $\beta$-agonist group of human medicine that licensed as a bronchodilator (treatment for asthma) in many countries. Its chemical structure (see Figure 1) is related to catecholamine's able to interact with adrenergic receivers, generally of the type $\beta_{2}$ (Valladares-Carranza et al. 2014). Clenbuterol with a common trade name Ventipulmin is not licensed as a growth promoting drug in European
Union (EU) (EC 2010), and also China and United States, but some countries still have approved it for food producing animals, and sometimes used at 5-10 times higher than common therapeutic doses. Therefore, this drug is also used illegally to promote animal livestock (including beef meat) growth, causing a considerable increase in muscular mass and, at the same time, a decrease in fat accumulation and improved feed efficiency (Trejo et al. 2013). The free fatty acids produced by CLB stimulation belonging to the $\beta$ group 
of adrenergic agonists to the fatty tissue will be used as an alternative energy source of muscle protein synthesis. The use of CLB has a positive impact on the environment due to reduce excretion of livestock.

The use of CLB for growth-promoting purposes has been prohibited in European countries, Mexico and some other countries (EC 2010; Valladares-Carranza et al. 2014). The reason of banning CLB use as a growth promoter in Europe is because its classification of class A animal drug with anabolic effects. Livestock products (meat and liver) containing CLB residues have the potential to increase heart rate and blood pressure, tachycardia, excessive anxiety, chills and muscle tremor (Brambilla et al. 2000). The maximum residue limit (MRL) for CLB permitted by WHO and Codex Alimentarius in meat is $0.2 \mathrm{ng} / \mathrm{g}$ and in liver is $0.6 \mathrm{ng} / \mathrm{g}$ (CAC 2012). The Codex Alimentarius Commission recommends MRLs for cattle are of $0.2 \mathrm{ng} / \mathrm{g}$ in muscle and fat, $0.6 \mathrm{ng} / \mathrm{g}$ in liver and kidney, and $0.05 \mathrm{ng} / \mathrm{mL}$ for cattle milk, expressed as parent drug (CAC 2012).

In some cases, the presence of non-negligible amounts of drug residues in meat is a real public health problem and causing food poisoned from eating liver and meat contained CLB residues. Fifteen people in Italy poisoned from eating beef contained CLB with concentrations of 1140-1480 ng/g (Brambilla et al. 2000), as well as in 50 people in Portugal from ingesting CLB residue in meat lamb contained 0.3 $\mathrm{mg} / \mathrm{kg}$ and liver lamb contained $1.4 \mathrm{mg} / \mathrm{kg}$ (Barbosa et al. 2005). In China, a person was died in Guangdong province in March 2006, also 300 people were poisoned in Shanghai in September 15, 2006 (Lai et al. 2008). The use of CLB in Indonesia also prohibited refer to the Act No. 18 of 2009 on Animal Husbandry and Animal Health (Articles 50-51) which had been amended by Act No. 41 of 2014 (Articles 19-23) and reinforced with Circular Letter of the Director General of Animal Husbandry and Animal Health Number 30059/HK.340/F/11/2011 and the Regulation of the Minister of Agriculture Number 14/PERMENTAN/ PK.350/5/2017.

Efficient methods are required for monitoring residue levels to ensure safety of food supply for human (Schneider et al. 2007) that might be done using a rapid screening method such as ELISA and lateral-flow assay (He et al. 2009; Lai et al. 2008) or confirmative method such as high performance liquid chromatography (Chang et al. 2005; Trejo et al. 2013). So far, no published reports on CLB residues exist on frozen and fresh beef meat circulated in Indonesian markets except official data published by BPMSPH (2015) after the case was revealed in local newspaper. This study reports the presence of CLB residue in beef meat samples originated from imported beef, fattening beef and local beef collected from several cities in Java Island using an adopted method developed by Trejo et al. (2013).

\section{MATERIALS AND METHODS}

\section{Chemical materials}

The standard of clenbuterol hydrochloride ( $\geq 95 \%)$ was obtained from Sigma-Aldrich (St. Louis, MO, USA). Chemicals such as methanol (p.a grade) acetonitrile (hplc grade), isopropanol (p.a grade), $\mathrm{NaCl}$, anhydrous $\mathrm{MgSO} 4$, anhydrous $\mathrm{Na}_{2} \mathrm{SO}_{4}, \mathrm{NaH}_{2} \mathrm{PO}_{4}$ were obtained from Merck (Germany) and PTFE $0.45 \mu \mathrm{m}$ (Waters, USA) microfilter. All aqueous solvents use water type 1 (ultra pure water/UPW) from Purelab Flex (Elga LabWater, UK).

\section{Sampling locations and collection}

Altogether 74 frozen or fresh meat samples (approximately 250 gr) collected and assisted by each District Livestock officers were collected during March to August 2013 from Tanjung Priok Port Quarantine for imported beef meat and a slaughterhouse in Jakarta for fattening beef meat, supermarkets for imported and traditional markets for fattening/local beef meat in Bandung, Semarang and Yogyakarta. The samples were grounded finely, stored in plastic bags and refrigerated at $-20^{\circ} \mathrm{C}$ until analysis. Samples were thawed at room temperature before analysis, then extracted and analyzed for CLB residue as described in the following method.<smiles>CC(C)(C)NC[C@H](O)c1cc(Cl)c(N)c(Cl)c1</smiles>

Figure 1. Chemical structure of clenbuterol (Valladares-Carranza et al. 2014). 


\section{Extraction and determination of CLB residue by HPLC}

The extraction process of the samples was adopted from a method developed by Trejo et al. (2013). A total of $5 \mathrm{~g}$ finely grounded beef meat was put into a $50 \mathrm{~mL}$ centrifuge tube and added by $4 \mathrm{~mL}$ of acetonitrile and 2 $\mathrm{mL}$ of isopropanol, then shaken for 30 seconds. The mixture was then added with $\mathrm{NaCl}$ of $1.2 \mathrm{~g}$ and vortexed for $2 \mathrm{~min}$, and then centrifuged for $10 \mathrm{~min}$ at $3500 \mathrm{rpm}$. Then the mixture was added with $4 \mathrm{~g}$ of anhydrous $\mathrm{Na}_{2} \mathrm{SO}_{4}$ and $0.5 \mathrm{~g}$ of $\mathrm{MgSO}_{4}$ and vortexed for 2 minutes and centrifuged for 15 minutes at 3500 $\mathrm{rpm}$. The resulting supernatant was then transferred into a $5 \mathrm{~mL}$ vial and dried using nitrogen at $40^{\circ} \mathrm{C}$ until dry. The dry residue was then reconstituted using $1 \mathrm{~mL}$ of ultra pure water (UPW) and filtered using a $0.45 \mu \mathrm{m}$ filter and ready to be analyzed with an HPLC.

The HPLC instrumentation used was a Shimadzu Prominence equipped with LC-20AD pump, SPD M20A photo diode array detector (Shimadzu, Japan), set at a wavelength of $210 \mathrm{~nm}$. Analytical separation was conducted using Shimp pack VP ODS column $(4,6$ x $150 \mathrm{~mm}$, i.d $5 \mu \mathrm{m}$, Shimadzu, Japan). The mobile phase was a mixture of $50 \mathrm{mM} \mathrm{NaH} \mathrm{NO}_{4} \quad(\mathrm{pH}$ 3.0)/acetonitrile $(80: 20, \mathrm{v} / \mathrm{v})$, filtered with a $0.45 \mu \mathrm{m}$ PTFE filter membrane (Waters, MA, USA) and was sonicated for 10 minutes and run at flow rate of 0.8 $\mathrm{mL} / \mathrm{min}$.

\section{RESULTS AND DISCUSSION}

\section{Method development for CLB detection}

The extraction method adopted from Trejo et al. (2013) for CLB residue detection in meat sample in this study is relatively fast, efficient, effective, environmentally friendly and does not require a purification process. The sample was extracted using acetonitrile followed by isopropanol to remove the fat from the sample matrix. Then the salt, sodium sulfate and magnesium sulfate were added to withdraw water from the sample matrix.

The CLB residue was then eluted isocratically using a mobile phase of a mixture of $50 \mathrm{mM} \mathrm{NaH} \mathrm{PO}_{4}(\mathrm{pH}$ $3.0)$ and acetonitrile ( $80: 20, \mathrm{v} / \mathrm{v}$ ) and detected by HPLC equipped with a photo diode array (PDA) detector at a wavelength of $210 \mathrm{~nm}$ with a typical chromatogram is shown in Figure 2. The CLB residue elutes at $6.0 \mathrm{~min}$. The use of PDA detector can confirm the positive samples by scanning the wavelength.

Several validation test parameters (recovery test, limit of detection and limit of quantitation) was carried out to verify this method meets the requirements to be applied in real field samples. The extraction efficiency (recovery test) of clenbuterol (CLB) was determined in triplicates at 2,5 , and $10 \mathrm{ng} / \mathrm{g}$ and subjected to extraction using the aforementioned method. The recovery of this study was assessed by analyzing a sample of known concentration and comparing the measured value to the true value and gave the results of $103.45 \%, 89.27 \%$, and $89.53 \%$ at the spiking concentration level of 2,5 , and $10 \mathrm{ng} / \mathrm{g}$, respectively (see Table 1). The values in line with those obtained by Trejo et al. (2013) in the range of 82 to $111.7 \%$ for spiking of CLB at concentration range of 5.24 to 41.96 $\mathrm{ng} / \mathrm{g}$. The values in line with those obtained by Trejo et al. (2013) in the range of 82 to $111.7 \%$ for spiking of CLB at concentration range of 5.24 to $41.96 \mathrm{ng} / \mathrm{g}$.

The calculations of detection limit and quantitation limit were $0.10 \mathrm{ng} / \mathrm{g}$ and $0.32 \mathrm{ng} / \mathrm{g}$, respectively. These values were close to the study conducted by Chang et al. (2005) namely $0.1 \mathrm{ng} / \mathrm{g}$, and still below the MRL established by the United Nations Food and Agricultural Organization for CLB of $0.2 \mathrm{ng} / \mathrm{g}$ (CAC 2012).

$\mathrm{uV}$

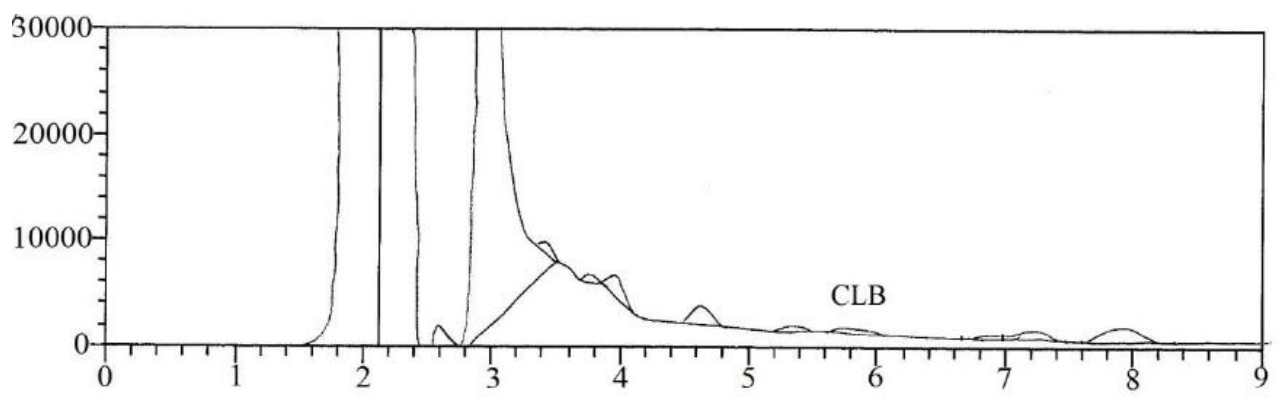

Figure 2. Chromatograms obtained from a positive sample in the presence of CLB residue. 


\section{Determination of CLB residues on field samples}

The use of CLB for cattle defattening is not allowed internationally. The major biotransformation pathways of CLB were 4-N-oxidation, 4-N-sulfation, and oxidative $\mathrm{N}$-dealkylation of the parent compound. Unchanged CLB accounted for about 20 and $50 \%$ of the radioactivity detected in urine and feces, respectively, and for a very large part of the radioactivity detected in organs $(\geq 90 \%)$, and therefore, the toxicity of CLB residues remaining in tissues of cattle treated with this $\beta$-agonist toward the consumer is expected to be solely related to unchanged CLB (Zalko et al. 1998).

Analysis of $36 \mathrm{local} /$ fattening beef meat samples collected from several cities in Java (Jakarta, Bandung, Semarang and Yogyakarta) collected from March to August 2013 is summarized in Table 2 and shown 7 (19.44\%) out of 36 samples were positive for CLB residue and exceeded the MRL set by Codex $(0.2 \mathrm{ng} / \mathrm{g})$ of about 12 to 75 times higher to Codex's recommendation. Those results above indicated there was a misuse that local/fattening cattle were possibility of being treated by CLB and slaughtered without paying attention to its the withdrawal time of 4 weeks for proper therapeutically treated livestock $(1.6 \mu \mathrm{g} / \mathrm{kg} / \mathrm{day}$ for 7 consecutive days) (Elliot et al. 1995). A study on CLB contamination from treated veal calves (2.5 $\mathrm{mL} / 100 \mathrm{~kg}$, twice a day for 10 days) to untreated pen mates showed its probably due to licking the mouth of the treated animal or saliva from the treated animal spoiling the floor (Groot et al. 2013).

Whereas Table 3 which summarized results for frozen imported beef meat samples showed only one $(2.63 \%)$ out of 38 samples was positive for CLB residue which meant that the supervision of the importing country was almost really well implemented.

Table 1. Average recoveries, detection limit and quantitation limit of CLB spiked in beef meat sample

\begin{tabular}{|c|c|c|c|c|}
\hline \multicolumn{3}{|c|}{ Average recoveries $(\%)$ at 3 different spiking levels $(\mathrm{n}=3)$} & \multirow{2}{*}{ Detection limit (ng/g) } & \multirow{2}{*}{ Quantitation limit (ng/g) } \\
\hline $2 \mathrm{ng} / \mathrm{g}$ & $5 \mathrm{ng} / \mathrm{g}$ & $10 \mathrm{ng} / \mathrm{g}$ & & \\
\hline 103.45 & 89.27 & 89.53 & 0.10 & 0.32 \\
\hline
\end{tabular}

Table 2. Residue analysis of CLB in local/fattening beef meat samples from Jakarta, Bandung, Yogyakarta, and Semarang collected from March to August 2013

\begin{tabular}{lccc}
\hline \hline Origin of samples & Number of samples & Number of positive samples & Concentration (ng/g) \\
\hline Jakarta & 10 & 5 & 7.09 to 15.06 \\
Bandung & 9 & nd & - \\
Semarang & 6 & nd & - \\
Yogyakarta & 11 & 2 & 2.40 and 2.42 \\
Total & 36 & 7 & 2.40 to 15.06 \\
\hline
\end{tabular}

nd $=$ not detected at concentration $\leq 0.09 \mathrm{ppb}$

Table 3. Residue analysis of CLB in imported beef meat samples from Jakarta, Bandung, Yogyakarta, and Semarang collected from March to August 2013

\begin{tabular}{lccc}
\hline \hline Origin of samples & Number of samples & Number of positive samples & Concentration (ng/g) \\
\hline Jakarta & 22 & 1 & 5.13 \\
Bandung & 4 & $\mathrm{Nd}$ & - \\
Semarang & 5 & $\mathrm{Nd}$ & - \\
Yogyakarta & 7 & $\mathrm{Nd}$ & - \\
\hline Total & 38 & 8 & 5.13 \\
\hline
\end{tabular}

nd $=$ not detected at concentration $\leq 0.09 \mathrm{ppb}$ 
A surveillance study in 2015 in Indonesia conducted by Balai Pengujian Mutu dan Sertifikasi Produk Hewan, in Bogor (BPMPSH) revealed that $10(14.49 \%)$ out of 69 beef samples and $26(22.22 \%)$ out of 117 liver beef samples were positive for on detection of beta agonist (clenbuterol/salbutamol) using ELISA (BPMSPH 2015) that also meant there is no difference on the $\beta$-agonist (CLB/salbutamol) residue status in beef meat in 2013 and 2015 in Indonesia. The main drawback of ELISA detection method was there no specification of types of $\beta$-agonist applied due to its inability to differentiate $\beta$ agonist drugs (CLB or salbutamol) from the same class.

This study better than those of Betancurt et al. (2008) in Mexico that received $16.6 \%$ of 90 meats in the range of $0.1-2.3 \mathrm{ng} / \mathrm{g}$ and Trejo et al. (2013) in 78 cow liver samples showing $62 \%$ of which contained more than $0.6 \mathrm{ng} / \mathrm{g}$ (above the MRL in America and FDA). Similarly, the results of research Hajrulai-Musliu et al. (2013) which detected 21 positive samples from 55 beef samples in Macedonia in the range of $1.19 \mathrm{ng} / \mathrm{g}$ to $0.5 \mathrm{ng} / \mathrm{g}$.

Administration of clenbuterol as a growth promoter in pig production could lead to residues in meat for human consumption up to 7 days after treatment discontinuation (Pleadin et al. 2010). Prolonged administration of a growth-promoting dose of CLB to cattle could lead to residue accumulation in the muscle tissue (meat) and liver as an edible tissue, which may induce a pharmacotoxicologic reaction in consumers. Several human poisoning cases had been reported in the presence CLB residues. Martínez-Navarro (1990) reported 135 people hospitalized in Spain in 1990 suffered the characteristic symptoms CLB poisoned (increased heart rate, muscle tremors, headache, nausea, fever, and chills) in fresh liver that contained $160 \mathrm{ng} / \mathrm{g}$ to $291 \mathrm{ng} / \mathrm{g}$ of CLB residue.

On the other hand, a strict monitoring of the CLB usage in Mexico showed a decline in CLB residue from $20 \%$ in 2006 to $7.1 \%$ as observed in 1221 samples consisting of various types of samples such as meat, liver, urine, cow serum in 2005-2010 (Almazan et al. 2012). However, data from inspection on 200 slaughterhouses in 2015 in Mexico still released that CLB residue was found on 58 out of them as the government gave suspension to those slaughterhouses (AP 2016).

Previous published report in Indonesia of another $\beta$ agonist drug of ractopamine which still permitted to be used (Widiastuti \& Anastasia 2015) on 14 imported beef meat also showed none of those samples positive for ractopamine residue, also meant that the importing country puts strong supervision on the use of these drugs. In contrast, health risks study on $14 \beta$-agonist residue (including ractopamine and clenbuterol) were assessed in cattle, chicken and swine livers at the wet market and the environmental impacts of wastewater from livestock farms in Selangor State, Malaysia showed 5 beta-agonists were detected in the wastewater samples (Sakai et al. 2016).

Urine and hair are the most frequently analyzed material for the detection of CLB (Sniegocki et al. 2003) which can be taken in both farm- and slaughterhouses. However, urine has a limitation that the concentration of $\beta$-agonists are below the limit of detection of most assays after a withdrawal time of 3 to 4 days, which makes urine suitable only for detection during treatment and less suitable for the detection of illegal use. Whereas, hair promised a better binding capacity of CLB due to presence of melanin in hair and made the residue could be accumulated up to 70 days after withdrawal (Li et al. 2013) and promised as an easy way of collecting samples before slaughtering the animal. Since the presence of CLB residues in food consumed can cause health problems for humans, the most important thing to improve public health is continous monitoring and prevention of CLB misuse is needed and to ensure the absence of contamination to the farm/livestock environment (Lee et al. 2007).

\section{CONCLUSIONS}

The detection of CLB in meat can be conducted by HPLC with the diode array detector after the sample extracted with acetonitrile and isopropanol. Analysis of CLB residues in 74 field samples consisting of imported beef, fattening and local beef meat from various cities in Java showed $8(10.81 \%)$ of those samples were detected CLB at concentrations of 2.40 and $15.06 \mathrm{ng} / \mathrm{g}$ that has exceeded the CLB's MRL recomendation by Codex and WHO (0.2 ng/g). Continuously monitoring and prevention of CLB misuse should always be done to avoid further risk to human health.

\section{ACKNOWLEDGEMENT}

This research was financially supported by the research grant from The Indonesian Ministry of Agriculture (DIPA-1806.023./2013). The authors also are grateful to all colleagues for their cooperation and permission to collect the samples.

\section{REFERENCES}

[AP] Associated Press. 2016. Mexico watches out for banned steroid clenbuterol in food. Fox News World.

Almazan LAC, Ortiz JAD, Cruz BP, Romero MAA. 2012. Trend in levels of clenbuterol in bovine samples from 2005 to 2010 in Guerrero, Mexico. Rev Mex Cienc Pecu. 3:449-458. 
Barbosa J, Cruz C, Martins J, Silva JM, Neves C, Alves C, Ramos F, Da Silveira MIN. 2005. Food poisoning by clenbuterol in Portugal. Food Add Contam. 22:563-566.

Betancurt SDP, Cordova-Izquierdo A, Uribe A, Michel AM. 2008. Clenbuterol residues in bovine feed and meat. Res J Biol Sci. 3:1444-1445.

Brambilla G, Cenci T, Franconi F, Galarinio R, Macri A, Rondoni F, Strozzi M, Loizzo A. 2000. Clinical and pharmacological profile in a clenbuterol epidemic poisoning of contaminated beef meat in Italy. Tox Lett. 114:47-53.

[BPMSPH] Balai Pengujian Mutu dan Sertifikasi Produk Hewan. 2015. Laporan Tahunan 2015 Balai Pengujian Mutu dan Sertifikasi Produk Hewan. Direktorat Kesehatan Masyarakat Veteriner, Dirjen Peternakan dan Kesehatan Hewan, Kementerian Pertanian. Bogor (Indones): Balai Pengujian Mutu dan Sertifikasi Produk Hewan.

Chang LY, Chou S-S, Hwang D-F. 2005. High performance liquid chromatography to determine animal drug clenbuterol in pork, beef and hog liver. J Food Drug Analysis. 13:163-167.

[CAC] Codex Alimentarius Commission. 2012. CAC/MRL 22012. Codex Alimentarius Commission. Maximum Residue Limits for Veterinary Drugs in Foods. July 2012. Updated as at the $35^{\text {th }}$ session of the Codex Alimentarius Commission. [accessed August 24 ${ }^{\text {th }} 2012$ ]. ftp://ftp.fao.org/codex/weblink/MRL2_e_2012.pdf.

Elliott CT, McCaughey WJ, Crooks SRH, McEvoy JDG, Kennedy DG. 1995. Residues of clenbuterol in cattle receiving therapeutic doses: Implications for differentiating between legal and illegal use. Vet Quarterly. 17:100-102.

[EC] European Commission. 2010. Commission Regulation (EU) No 37/2010 of December 22th, 2009, on pharmacologically active substances and their classification regarding maximum residue limits in foodstuffs of animal origin. [accessed October 12th 2012]. http://ec.europa.eu/health/files/eudralex/vol5/reg_2010_37/reg_2010_37_en.pdf;2010.

Groot MJ, Lasaroms JJ, van Bennekom EO, Van Hende J, Nielen MW. 2013. Possible contamination with clenbuterol from treated veal calves to untreated pen mates. Food Addit Contam Part A Chem Anal Control Expo Risk Assess. 30:1063-1067.

Hajrulai-Musliu Z, Uzunov R, Stojkovski, DimitrieskaStojkovik E, Stojanosvska-Dimziska B, Sekulosvski P. 2013. Determination of clenbuterol in meat samples with ELISA and GC-MS method. Proceeding 1st Annual International Interdisciplinary Conference. Azores (Portug): AIIC. p. 817-824.

He L, Pu C, Yang H, Zhao D, Deng A-P. 2009. Development of a polyclonal indirect ELISA with sub-ng g-1 sensitivity for the analysis of clenbuterol in milk, animal feed, and liver samples and a small survey of residues in retail animal products. Food Add Contam. 26:11531161.

Lai WH, Fung DYC, Xu Y, Xiong YH. 2008. Screening Procedures for Clenbuterol Residue Determination in Raw Swine Livers Using Lateral-Flow Assay and Enzyme-Linked Immunosorbent Assay. J Food Prot. 71:865-869.

Lee HB, Sarafin K, Peart TE. 2007. Determination of $\beta$ blockers and $\beta 2$-agonist in sewage by solid phase extraction and liquid chromatography tandem mass spectrometry. J Chromatography A. 1148:158-167.

Li L, Zhang J, Tang C, Zhao Q. 2014. Accumulation of clenbuterol residues in the hair of Chinese Simmental beef cattle during and after treatment. J Anal Toxicol. 38:52-56.

Martinez-Navarro JF. 1990. Food poisoning related to consumption of illicit beta-agonist in liver. Lancet. 336:1311

Pleadin J, Vulić A, Persi N, Vahcić N. 2010. Clenbuterol residues in pig muscle after repeat administration in a growth-promoting dose. Meat Sci. 86:733-737.

Sakai N, Sakai M, Mohamad Haron DE, Yoneda M, Ali Mohd M. 2016. Beta-agonist residues in cattle, chicken and swine livers at the wet market and the environmental impacts of wastewater from livestock farms in Selangor State, Malaysia. Chemosphere. 165:183-190.

Schneider MJ, Darwish AM, Freeman DW. 2007. Simultaneous multiresidue determination of tetracyclines and fluoroquinolones in catfish muscle using high performance liquid chromatography with fluorescence detection. Anal Chim Acta, 586:269-274.

Sniegocki T, Zmudzki J, Posyniak A, Semeniuk S. 2003. Gas chromatography-mass spectrometric confirmatory method for the determination of clenbuterol residues in animal urine and liver samples. Bull Vet Inst Pulawy. 47:139-144.

Trejo FM, Leon SV, Medina AS, Tolentino RG. 2013. Application of high performance liquid chromatography-UV detection to quantification of clenbuterol in bovine liver samples. J Food Drug Anal. 21:414-420.

Valladares-Carranza B, Bañuelos-Valenzuela R, PenaBetancourt SD, Velazquez-Ordonez V, VelazquezArmenta Y, Nava-Ocampo A. 2014. Illegal use of clenbuterol in cattle production in México. Health. 6:673-676.

Widiastuti R, Anastasia Y. 2015. Ractopamine residue in imported beef meat in Indonesia. Noor SM, Handiwirawan E, Martindah E, Widiastuti R, Sianturi RSG, Herawati T, Purba M, Anggraeny YN, Batubara A, editors. Proceeding Animal Livestock and Veterinary Technology. Bogor (Indones): Indonesian Center for Animal Research and Development. p. 197-203. 